Ekspansi: Jurnal Ekonomi, Keuangan, Perbankan dan Akuntansi

ISSN (Online): 2580-7668 ISSN (Print): 2085-5230

Vol. 11, No. 2 (November 2019), Hal. 199 - 210

\title{
KORELASI ANTARA VARIABEL DEMOGRAFI DENGAN TINGKAT ADOPSI E-BANKING
}

\author{
Sri Widiyati ${ }^{1}$, Embun Duriany ${ }^{2}$ \\ ${ }^{1,2}$ Jurusan Akuntansi Politeknik Negeri Semarang, Semarang, Indonesia \\ Email Korespondensi: wiwidsoemodipoero@yahoo.co.id
}

\begin{abstract}
Service innovations that have been carried out by banks will succeed depending on the intention of adoption and the intention of loyal customers in using E-Banking. The higher the intention of adoption and the intention of loyalty towards banking innovation, the stronger the banking system, the financial system is not easily fragile and the national economy is stronger. The research problem is how the correlation between demographic variables with the level of adoption of E-Banking. Sampling is purposive sampling and data is collected by using a questionnaire. Data analysis using cross tabulation and using Chi Squared. Statistical test results show that gender and education level do not correlate with E-Banking adoption rates while age and occupation variables have a correlation with E-Banking adoption rates.
\end{abstract}

Keywords: E-Banking, adoption rate, demographic variables, Chi-Squared

Abstrak: Inovasi pelayanan yang telah dilakukan oleh perbankan akan berhasil bergantung pada niat adopsi dan niat loyal nasabah dalam penggunakan E- Banking. Semakin tinggi niat adopsi dan niat loyal terhadap inovasi perbankan maka perbankan semakin kuat, system keuangan tidak mudah rapuh dan ekonomi nasional semakin kuat. Permasalahan penelitian adalah bagaimana korelasi antara variabel demografi dengan tingkat adopsi EBanking.Pengambilan sampel secara purposive sampling dan data dikumpulkan dengan mernggunkan kuestioner. Analisis data menggunakan tabulasi silang serta menggunakan Chi Squared. Hasil uji statistik memperlihatkan bahwa variabel gender dan tingkat pendidikan tidak berkorelasi dengan tingkat adopsi E-Banking sedangkan variabel usia dan pekerjaan memiliki korelasi dengan tingkat adopsi E-Banking.

Kata Kunci: E-Banking, tingkat adopsi, variabel demografi, Chi-Squared

DOI: $10.35313 /$ ekspansi.v11i2.1528

Riwayat Artikel:

Diterima: $01-09-2019$

Direvisi: $21-11-2019$

Disetujui: $24-11-2019$ 


\section{PENDAHULUAN}

Pada industri perbankan, layanan perbankan banyak didukung dengan keberadaan internet. Layanan self service technologies mendukung untuk memandirikan nasabah (Curran dan Meuter, 2005). Electronic transaction merupakan salah satu bentuk baru pengembangan delivery channel pelayanan bank yang telah mengubah strategi bisnis perbankan yang semula lebih banyak mengandalkan pada teknologi manusia menjadi teknologi informasi. Sejalan dengan perkembangan teknologi informasi di atas, peranan electronic banking (E-Banking) semakin berarti. E-Banking (internet banking; SMS banking; mobile banking) dapat dilakukan di mana saja dan kapan saja.

Hasil survey memperlihatkan jumlah pengguna internet banking meningkat dari tahun ke tahun seiring dengan meningkatnya pengguna internet di Indonesia. Hal ini dapat dilihat pada gambar 1 .
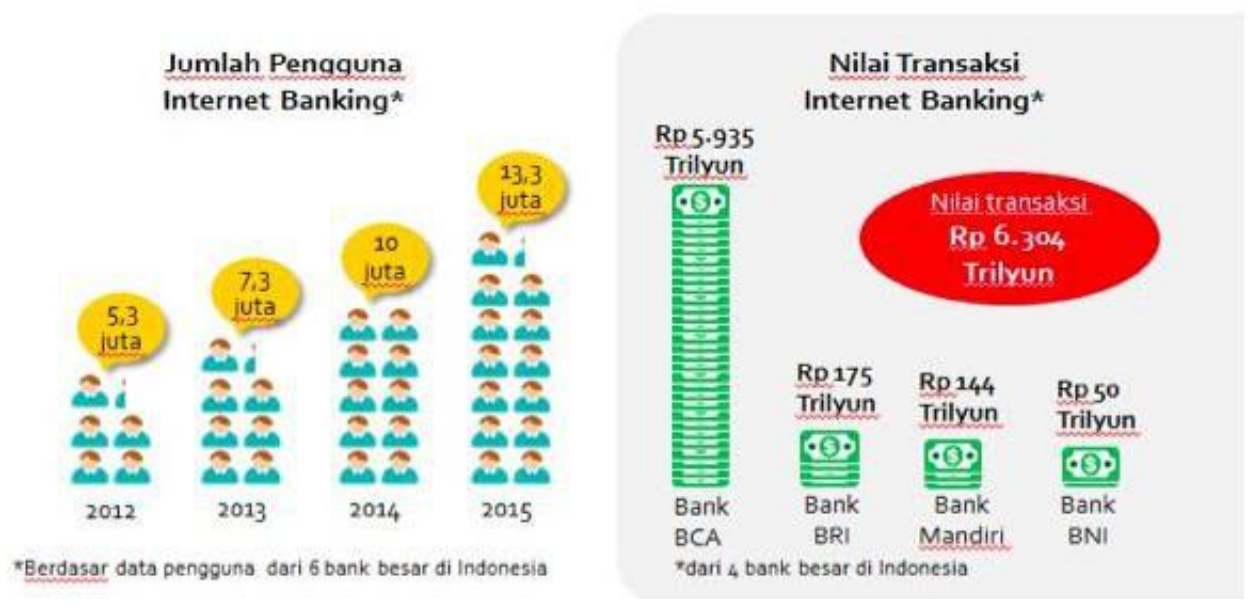

Sumber: Sharingvision.com

Gambar 1: Jumlah Pengguna Internet Banking dan Nilai Transaksi Tahun 2016

Dilihat dari jumlah pengguna E-Banking (internet banking, phone banking, SMS banking, mobile banking), terdapat kenaikan yang signifikan. Tahun 2012 pengguna ebanking 13,6 juta nasabah meningkat menjadi 50,4 juta nasabah pada tahun 2016. Kenaikan yang terjadi sebesar $270 \%$. Penetrasi penggunaan teknologi digital yang besar di Indonesia, maka salah satu fokus utama pemerintah adalah ekonomi digital. Pada tahun 2020, Indonesia diharapkan menjadi kekuatan ekonomi digital terbesar di kawasan Asia.

Di sisi lain, inklusi perbankan di Indonesia belum tinggi. Penduduk Indonesia yang mengkonsumsi perbankan baru sekitar 70 juta diantara 250 juta penduduk. Hal ini memperlihatkan bahwa $72 \%$ adalah unbankable. Memahami gap layanan dan potensi pemanfaatan teknologi yang demikian besar, peningkatan pemanfaatan $\mathrm{E}$ Banking diharapkan dapat memperluas jangkauan layanan dan menyiasati tantangan geografis.

Layanan yang bersifat no face to face contact semakin berkembang maka adopsi $e$ banking membutuhkan proses edukasi sehingga mampu membentuk niat adopsi bagi pengguna. Adopsi teknologi bagi perbankan maupun nasabah merupakan tantangan sekaligus konsekuensi risiko (Chen, 2013; Akturan dan Tezcan, 2012). Bagi organisasi, 
adopsi teknologi bergantung pada faktor ekternal yaitu produk informasi di pasar; tekanan persaingan di luar; konsultan atau vendor Informasi teknologi; serta regulasi pemerintah. Sedangkan faktor internal organisasi yaitu karakteristik management/pemilik; perilaku dan karakteristik organisasi; sumber daya yang dimiliki organisasi serta pengguna informasi teknologi (Ghobakhloo cs, 2012).

Perkembangan teknologi memberikan peluang perbankan untuk berinovasi dalam pengembangan layanan terbaik untuk nasabah dan di sisi lain niat adopsi nasabah untuk menerima pembaruan dipengaruhi banyak faktor. Dengan demikian, adopsi teknologi memberikan konsekuensi bagi perbankan dan nasabah karena keduanya berkepentingan dengan layanan baru yang memberikan kemudahan, kecepatan, ketepatan, dan kenyamanan (Cudjoe,et.al.,2015). Bagi nasabah, persoalan mendasar adopsi teknologi tidak terlepas dari aspek manfaat yang akan diterima. Karena itu edukasi tentang kemanfaatan adopsi E-Banking perlu dilakukan pihak perbankan. Jika nasabah gagal mendapat kemanfaatan dari adopsi E-Banking maka niat adopsi tidak akan berhasil. Untuk itu maka determinan adopsi teknologi perlu diketahui.

\section{TINJAUAN PUSTAKA}

Proses adopsi melalui beberapa tahapan yaitu kesadaran (awareness) yaitu sasaran mulai sadar tentang adanya inovasi yang ditawarkan; perhatian (interest) yaitu tumbuhnya minat yang seringkali ditandai oleh keinginannya untuk bertanya atau untuk mengetahui lebih banyak/jauh tentang segala sesuatu yang berkaitan dengan inovasi yang ditawarkan; penaksiran (evaluation) yaitu penilaian terhadap baik buruk atau manfat inovasi yangtelah diketahui informasinya secara lengkap serta penilaian terhadap aspek teknisnya saja, tetapi juga aspek ekonomi, maupun aspek-aspek sosial budaya, bahkan seringkali juga ditinjau dari aspek politis atau kesesuaiannya dengan kebijakan pembangunan nasional dan regional, percobaan (trial) yaitu mencoba dalam skala kecil untuk lebih meyakinkan penilaiannya, sebelum menerapkan untuk skala yang lebih luas lagi; adopsi yaitu menerima/menerapkan dengan penuh keyakinan berdasarkan penilaian dan uji coba yang telah dilaku-kan/diamatinya sendiri dan konfirmasi yaitu (Mundy, 2000). Adopsi dipengaruhi oleh banyak faktor yaitu : sifatsifat atau karakteristik inovasi; sifat-sifat atau karakteristik calon pengguna; pengambilan keputusan adopsi; saluran atau media yang digunakan; kualifikasi penyuluh

Beberapa penelitian berkaitan dengan variabel penentu adopsi teknologi telah dilakukan tetapi hasil penelitian memperlihatkan belum adanya kesepakatan (inconclusive) mengenai apa yang menjadi determinan adopsi E-Banking. Dalam kaitan dengan daya adopsi mobile financial services maka faktor penentu adalah personal habit dan kemudahaan penggunaan serta kemanfaatan yang diperoleh (Feng Shang Wu dan Yung Shen Yen , 2014). Sementara individu yang sulit mengadopsi teknologi seperti mobile banking karena persepsi resiko yang mungkin terjadi relatip besar. Tetapi, apabila persepsi kenikmatan yang akan diperoleh maka dampak adopsi menjadi positip seperti teknologi baru akan membuat kemudahan serta mendapatkan keuntungan. Faktor 
penentu adopsi teknologi juga terletak pada tingkat reliabilitas dari service yang dihasilkan teknologi tersebut (Ndumba Hannah Wangari dan Muturi Willy, 2014).

Meskipun seringkali individu menyadari pentingnya mobile money karena akan menghemat waktu tetapi daya adopsi terhadap perubahan teknologi tersebut rendah. Hal ini dikarenakan jaringan agen yang lemah serta dukungan pengguna juga lemah. Dukungan pengguna yang rendah akibat kelangkaan pelatihan, ketakutan akan keamanan uang serta biaya transaksi yang tinggi ( Pamela John Chogo dan Eliamani , 2014).

Hal lain yang menjadi perhatian dalam kaitan adopsi teknologi adalah perceived usefulness; perceived easy to use; awarness dan perceived risk (Rahmath Safeena, Hema Date, Abdullah Kammani, and Nisar Hundewale , 2012 ). Perceived usefullness ( kemanfaatan) merupakan unsur yang dipertimbangan dalam adopsi. Seberapa besar kemanfaatan teknologi akan meningkatkan prestasi kerja. Perceived easy to use ( kemudahaan penggunaan) yaitu tingkatan di mana seseorang merasa memperoleh kemudahaan dalam bertransaksi. Awarness ( kesadaran) akan berkaitan dengan karakteristik layanan inovatip dan perceived risk ( resiko yaitu seberapa besar kemungkinan kerugian akan muncul dengan penggunaan teknologi.

Determinan adopsi teknologi juga berkaitan dengan service quality, system quality, reputation, structural assurance, perceived credibility and perceived financial cost . Variabel service quality, system quality, reputation dan perceived credibility berpengaruh positip terhadap adopsi tehnologi sementara perceived financial cost berpengaruh negatip signifikan (A.A.,Chaudry, A.,Parveiz, Y., Javed, 2016).

Dalam Unified Theory of Acceptance and Use of Technology, terdapat beberapa faktor penting dalam mengadopsi Branchless Banking adalah performance expectancy,effort expectancy, social influence, facilitiating condition serta dua penentu langsung yakni intention dan facilitiating conditions. Faktor - faktor moderating seperti usia, gender, tingkat Pengalaman dan voluntariness of use.

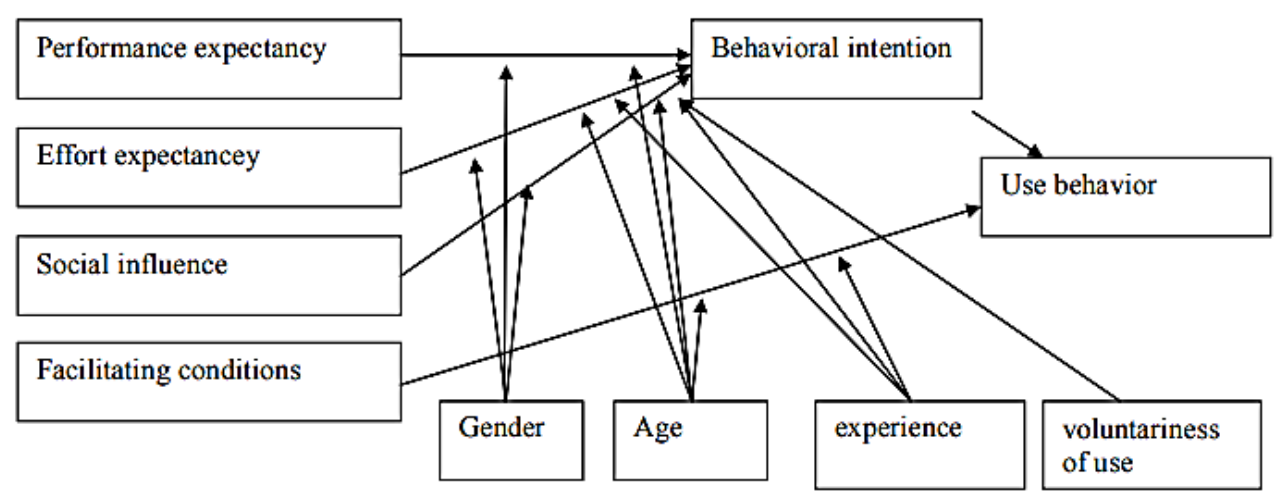

Sumber : Xiaoguang Shi :2011

\section{Gambar 2. Unified Theory of Acceptance and Use of Technology}

Dari berbagai hasil penelitian di atas, belum terlihat adanya variabel demografi yang menjadi penentu adopsi E-Banking. Variabel demografi seperti gender, usia, pekerjaan, pendidikan memiliki peran dalam adopsi teknologi. Maka pada penelitian 
ini akan mengeksplorasi determinan adopsi dengan memasukan variabel demografi, sehingga permasalahan penelitian bagaimana korelasi riabel demograi dengantingkat adopsi E-Banking.

\section{METODE PENELITIAN}

Responden adalah pengguna E-Banking di Semarang. Teknik pengambilan sampel adalah purposive sampling. Kriteria yang digunakan adalah pengguna telah menggunakan E-Banking lebih dari 1 bulan.

Penentuan jumlah sampel jika populasi tidak diketahui dapat menggunakan formula sebagai berikut :

di mana :

$$
\mathrm{n}=\frac{Z}{4(\mathrm{moe})^{2}}
$$

$\mathrm{n}$ adalah jumlah sampel; $\mathrm{z}$ adalah tingkat keyakinan (95 \%)

moe adalah margin of error atau kesalahan maksimal yang bisa ditolerir $10 \%$

Maka dari perhitungan diperoleh jumlah sampel sebanyak :

$\mathrm{n}=\frac{(1,96)^{2}}{4(0,10)^{2}}=96,04$ dibulatkan menjadi 100. Dalam penelitian ini sampel yang akan diambil sebanyak 100 responden.

Pengambilan data menggunakan dengan menggunakan kuestioner dan depth interview. Kuestioner didesain dengan pertanyaan tertutup dimana sudah ada alternatip jawaban dan pertanyaan terbuka. Kuestioner dibagi menjadi dua bagian. Bagian pertama berisikan pertanyaan menggali profil responden dilihat dari faktor demografis .Bagian ke dua ,struktur pertanyaan digunakan untuk mengetahui determinan adopsi nasabah e banking di Semarang. Pernyataan/pertanyaan tertutup dengan jawaban menggunakan skala Likert (skala 1 jika jawaban sangat tidak setuju dan skala 5 adalah sangat setuju).

Alat analis yang digunakan yaitu : Uji Validitas dan Reliabilitas dan Uji Chi Square. Uji ini digunakan untuk mengetahui korelasi antara variabel demografi dengan tingkat adopsi. Uji Chi Square digunakan untuk menguji dua kelompok data baik variabel independen maupun dependennya berbentuk kategorik.

\section{HASIL DAN PEMBAHASAN}

\subsection{Gambaran Umum Responden}

Jumlah responden laki-laki dan perempuan seimbang masing-masing 50 orang. Dilihat dari jenis pekerjaan, pekerjaan responden bervariasi. Status responden mulai mahasiswa, masih bekerja sampai pensiun. 59 responden bekerja baik sebagai pegawai negeri, pegawai swasta maupun bekerja mandiri atau wiraswasta. Mahasiswa berjumlah 19 orang, 13 responden telah pensiun dan 9 responden adalah ibu rumah tangga. Tingkat pendidikan responden mulai SLTA sampai S3. Karena masih berstatus mahasiswa D3/S1 maka tingkat pendidikan dikategorikan SLTA dan hanya 11 responden berstatus S3. Dilihat dari segi usia, usia responden sangat bervariasi. 
Tabel 1. Alasan Menggunakan E-Banking

\begin{tabular}{|l|l|l|}
\hline No & Keterangan & $\begin{array}{l}\text { Jumlah } \\
\text { Responden }\end{array}$ \\
\hline 1 & Alasan menggunakan E - Banking ( internet,SMS dan mobile Banking) : & \\
& a. Dapat digunakan setiap saat. & 49 \\
& b. Hemat waktu dan energi. & 51 \\
& c. Fitur lengkap dan sesuai kebutuhan. & 48 \\
& d. Tidak menggunakan peralatan khusus. & 52 \\
& e. Kerahasiaan terjamin. & 48 \\
& f. Akses mudah. & 46 \\
\hline 2 & Fasilitas yang digunakan pada E-Banking: & \\
& a. Cek saldo. & 67 \\
& b. Pembayaran tagihan. & 54 \\
& c. Transfer antar rekening pada bank yang bersangkutan maupun & 49 \\
& bank lain. & \\
& d. Pembelian on line. & 38 \\
& e. Informasi suku bunga. & 22 \\
& f. Informasi kurs mata uang. & 19 \\
& g. Lainnya & 32 \\
\hline 3 & Peralatan yang digunakan untuk E-Banking (internet, SMS dan Mobile & \\
& Banking) & 43 \\
& a. Lap top /PC & 28 \\
& b. Tablet & 65 \\
& c. Mobile Phone & 67 \\
\hline
\end{tabular}

Sumber: Olah Data Tim Peneliti 2019.

Dari paparan tabel di atas, tampak bahwa berbagai alasan dikemukakan responden untuk menggunakan E- Banking. 52 responden memiliki alasan menggunakan $\mathrm{E}$ Banking karena tidak menggunakan peralatan khusus. Dengan HP, Laptop maupun tablet, E Banking sudah bisa dimanfaatkan. Dengan E-Banking, nasabah mendapatkan kemudahan untuk mengecek saldo, melakukan pembayaran, transfer maupun memperoleh informasi tentang suku bunga, kurs mata uang. Alasan yang mendominasi dalam menggunakan E- Banking adalah cek saldo.

\subsection{Hubungan antara Tingkat Adopsi E-Banking dengan Gender}

Perkembangan teknologi informasi mengakibatkan industri Perbankan mengimbangi bentuk layanan Perbankan yang sesuai dengan era teknologi. E-Banking merupakan layanan yang diberikan kepada nasabah. Layanan baru memberikan konsekuensi tidak hanya industri Perbankan tetapi juga nasabah. Keinginan nasabah menerima hal yang baru tergantung faktor yang menjadi pertimbangan.

Pada tabel 2 memeperlihatkan hasil tabulasi silang antara tingkat adopsi E-Banking dengan gender. Pada penelitian ini daya adopsi di klasifikasikan menjadi tiga yakni daya adopsi rendah, sedang dan tinggi. 
Tabel 2 Hubungan antara Tingkat Adopsi E-Banking dengan Gender

GENDER * ADOPSI Crosstabulation

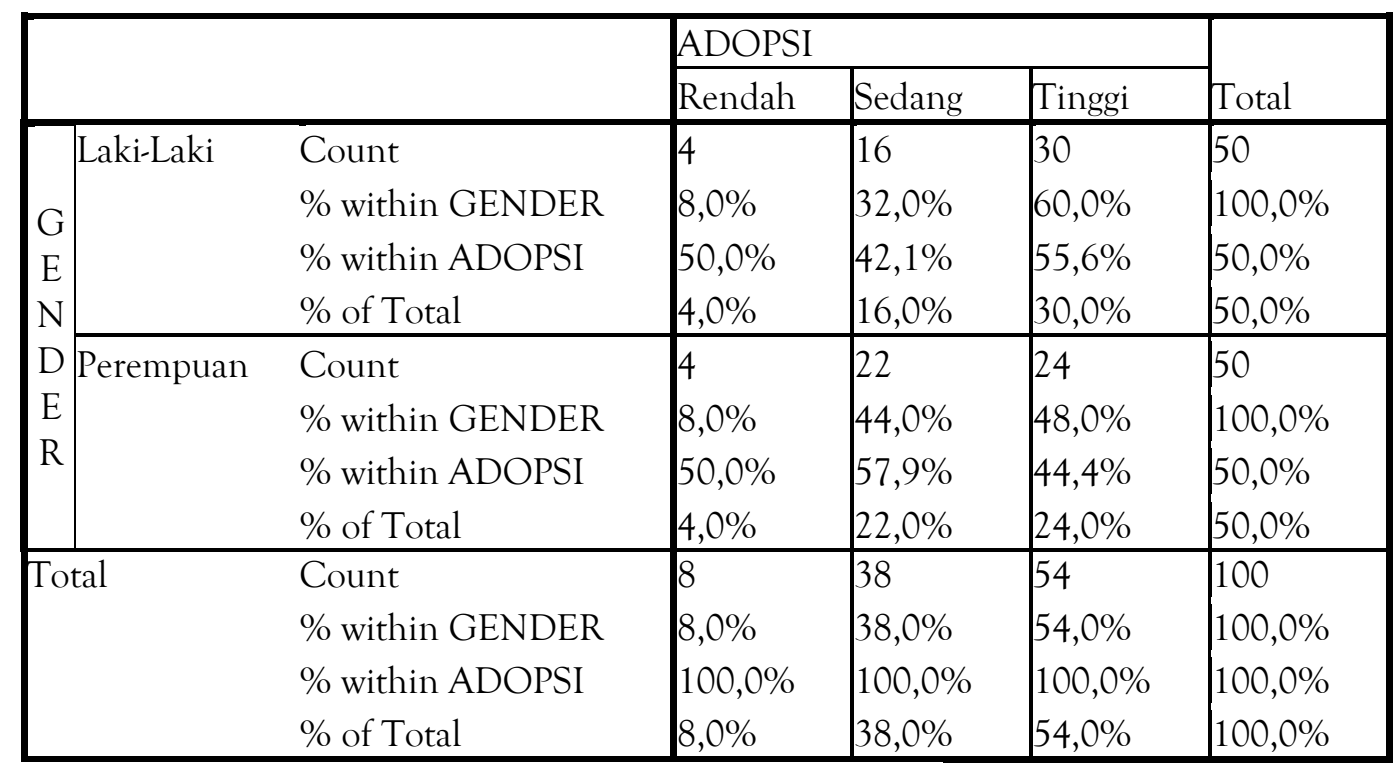

Sumber : Hasil Olah Data Tim Peneliti tahun 2019

Tabel 2 memperlihatkan bahwa jumlah responden dengan jenis kelamin laki-laki dan perempuan jumlahnya seimbang. Mayoritas laki-laki maupun perempuan memiliki daya adopsi terhadap E-Banking tinggi. Dilihat dari seluruh responden, maka $54 \%$ responden mempunyai daya adopsi tinggi , $38 \%$ dengan tingkat adopsi sedang dan sisanya $8 \%$ memiliki daya rendah.

Pada kelompok responden laki-laki, $60 \%$ responden tingkat adopsi E-Banking tergolong tinggi, $32 \%$ termasuk daya adopsi sedang dan sisanya $8 \%$ responden memiliki daya adopsi rendah. Pada kelompok responden berjenis kelamin perempuan, $48 \%$ responden mempunyai daya adopsi tinggi, $44 \%$ mempunyai daya adopsi sedang dan sisanya memiliki daya adopsi rendah.

Sesuai dengan paparan di atas dapat disimpulkan bahwa tidak ada perbedaan antara laki-laki dalam beradopsi terhadap E- Banking. Pernyataan ini dikuatkan dengan hasil uji Chi -Squares test yang menunjukan nilai sebesar 1.614 dengan probabilitas signifikansi 0.446. Oleh karena nilai signifikansi jauh di atas 0.05 maka dapat dijelaskan bahwa tidak ada hubungan /asosiasi antara gender dan daya adopsi E Banking. Hal ini juga diperkuat dengan besar Contingency Coefficient sebesar 0.126

\subsection{Hubungan antara Tingkat Adopsi E-Banking dengan Usia}

Tabel 3. Hubungan antara Tingkat Adopsi E-Banking dengan Usia

USIA * ADOPSI Crosstabulation

\begin{tabular}{|lll|l|l|l|l|}
\hline & & \multicolumn{2}{l|}{ ADOPSI } & Total \\
\cline { 3 - 7 } & & Rendah & Sedang & Tinggi & \\
\hline USIA sampai dengan 20 tahun & Count & 0 & 4 & 14 & 18 \\
& & $\%$ within USIA & $0,0 \%$ & $22,2 \%$ & $77,8 \%$ & $100,0 \%$ \\
& \% within ADOPSI & $0,0 \%$ & $10,5 \%$ & $25,9 \%$ & $18,0 \%$ \\
& \% of Total & $0,0 \%$ & $4,0 \%$ & $14,0 \%$ & $18,0 \%$ \\
\hline & Count & 0 & 5 & 11 & 16 \\
\hline
\end{tabular}


USIA * ADOPSI Crosstabulation

\begin{tabular}{|c|c|c|c|c|c|c|}
\hline & & & ADOPSI & & & Total \\
\hline & & & Rendah & Sedang & Tinggi & \\
\hline & & $\%$ within USIA & $0,0 \%$ & $31,3 \%$ & $68,8 \%$ & $100,0 \%$ \\
\hline & & \% within ADOPSI & $0,0 \%$ & $13,2 \%$ & $20,4 \%$ & $16,0 \%$ \\
\hline & & $\%$ of Total & $0,0 \%$ & $5,0 \%$ & $11,0 \%$ & $16,0 \%$ \\
\hline & 31 Th. - 40 Th. & Count & 0 & 5 & 7 & 12 \\
\hline & & $\%$ within USIA & $0,0 \%$ & $41,7 \%$ & $58,3 \%$ & $100,0 \%$ \\
\hline & & $\%$ within ADOPSI & $0,0 \%$ & $13,2 \%$ & $13,0 \%$ & $12,0 \%$ \\
\hline & & $\%$ of Total & $0,0 \%$ & $5,0 \%$ & $7,0 \%$ & $12,0 \%$ \\
\hline & 41 Th. - 51 Th. & Count & 1 & 10 & 8 & 19 \\
\hline & & $\%$ within USIA & $5,3 \%$ & $52,6 \%$ & $42,1 \%$ & $100,0 \%$ \\
\hline & & $\%$ within ADOPSI & $12,5 \%$ & $26,3 \%$ & $14,8 \%$ & $19,0 \%$ \\
\hline & & $\%$ of Total & $1,0 \%$ & $10,0 \%$ & $8,0 \%$ & $19,0 \%$ \\
\hline & 51 Th. $-60 \mathrm{Th}$ & Count & 4 & 8 & 11 & 23 \\
\hline & & $\%$ within USIA & $17,4 \%$ & $34,8 \%$ & $47,8 \%$ & $100,0 \%$ \\
\hline & & \% within ADOPSI & $50,0 \%$ & $21,1 \%$ & $20,4 \%$ & $23,0 \%$ \\
\hline & & $\%$ of Total & $4,0 \%$ & $8,0 \%$ & $11,0 \%$ & $23,0 \%$ \\
\hline & 61 Th. 70 Th. & Count & 3 & 6 & 3 & 12 \\
\hline & & \% within USIA & $25,0 \%$ & $50,0 \%$ & $25,0 \%$ & $100,0 \%$ \\
\hline & & $\%$ within ADOPSI & $37,5 \%$ & $15,8 \%$ & $5,6 \%$ & $12,0 \%$ \\
\hline & & $\%$ of Total & $3,0 \%$ & $6,0 \%$ & $3,0 \%$ & $12,0 \%$ \\
\hline Tota & & Count & 8 & 38 & 54 & 100 \\
\hline & & $\%$ within USIA & $8,0 \%$ & $38,0 \%$ & $54,0 \%$ & $100,0 \%$ \\
\hline & & \% within ADOPSI & $100,0 \%$ & $100,0 \%$ & $100,0 \%$ & $100,0 \%$ \\
\hline & & $\%$ of Total & $8,0 \%$ & $38,0 \%$ & $54,0 \%$ & $100,0 \%$ \\
\hline
\end{tabular}

Sumber : Hasil Olah Data Tim Peneliti tahun 2019

Industri Perbankan merupakan salah satu industri yang padat teknologi. Hal ini berakibat bergesernya transaksi pembayaran bersifat cashless. Kemajuan teknologi yang pesat akan memunculkan uang digital. Nasabah Perbankan mau tidak mau harus mengadopsi teknologi baru kalau tidak ingin tertinggal.

Dilihat dari sisi usia memang daya serap terhadap perkembangan teknologi berbeda. Manusia yang sudah begitu lama dan terbiasa dengan pelayanan Perbankan non cashless akan merasa kurang nyaman dengan perubahan yang baru. Pada tabel 3, usia nasabah sampai dengan 40 tahun memiliki tingkat adopsi terhadap E-Banking dalam kategori sedang dan tinggi. Biasanya anak muda keinginan untuk mengetahui sesuatu yang baru relatip lebih tinggi.

Semakin bertambah usia, jumlah responden dengan tingkat adopsi rendah semakin bertambah. Usia 41 tahun -50 tahun terdapat 1 orang responden dengan daya adopsi rendah; usia 51 tahun - 60 tahun terdapat 4 orang responden; usia 61 tahun 70 tahun terdapat 3 orang responden dengan daya adopsi rendah.

Berdasarkan paparan di atas, variabel usia sangat mempengaruhi tingkat adopsi EBanking. Hasil Chi-Squared memperlihatkan bahwa hubungan antara tingkat usia dan tingkat adopsi sebesar 18,830 dengan probabilitas signifikasi 0.042 .Nilai tersebut di 
bawah 0.05 maka dapat disimpulkan bahwa terdapat hubungan antara usia dan tingkat adopsi.Koefisien Contingencysebesar 0,398 berarti korelasi antara usia dengan tingkat adopsi belum kuat.

\subsection{Hubungan antara Tingkat Adopsi E-Banking dengan Pekerjaan}

Era digital telah memasuki kehidupan manusia. Kegiatan manusia digerakan dengan serangkaian teknologi digital. Hubungan antar manusia, manusia dengan pekerjaan kerap kali digerakkan dengan teknologi digital seperti komputer, internet, mesin ATM, hand phone dan sebagainya. Teknologi akan membawa perubahan dalam pekerjaan. Kehadiran teknologi akan mempercepat terselesainya suatu pekerjaan karena kemudahan yang diberikan oleh teknologi. Dalam dunia bisnis, kehadiran teknologi akan mempermudah transaksi. Kewajiban bayar membayar dapat diselesaikan tanpa harus datang langsung ke tempat pembayaran.

Teknologi sangat dibutuhkan dalam berbagai jenis pekerjaan maupun profesi. Teknologi dapat mempermudah pekerjaan sekaligus mempermudah berinteraksi dengan rekan kerja.Tingkat adopsi terhadap E- Banking dikaitkan dengan jenis pekerjaan terlihat pada tabel di bawah ini.

Tabel 4. Hubungan antara Tingkat Adopsi E-Banking dengan Pekerjaan PEKERJAAN * ADOPSI Crosstabulation

\begin{tabular}{|c|c|c|c|c|c|}
\hline & \multicolumn{3}{|c|}{ ADOPSI } & \multirow[b]{2}{*}{ Total } \\
\hline & & Rendah & Sedang & Tinggi & \\
\hline \multicolumn{2}{|c|}{ EKERJAAN MAHASISWA Count } & 0 & 6 & 13 & 19 \\
\hline & \% within PEKERJAAN & $0,0 \%$ & $31,6 \%$ & $68,4 \%$ & $100,0 \%$ \\
\hline & $\%$ within ADOPSI & $0,0 \%$ & $15,8 \%$ & $24,1 \%$ & $19,0 \%$ \\
\hline & $\%$ of Total & $0,0 \%$ & $6,0 \%$ & $13,0 \%$ & $19,0 \%$ \\
\hline \multirow[t]{4}{*}{$\overline{\mathrm{PNS}}$} & Count & 5 & 8 & 9 & 22 \\
\hline & $\%$ within PEKERJAAN & $22,7 \%$ & $36,4 \%$ & $40,9 \%$ & $100,0 \%$ \\
\hline & $\%$ within ADOPSI & $62,5 \%$ & $21,1 \%$ & $16,7 \%$ & $22,0 \%$ \\
\hline & $\%$ of Total & $5,0 \%$ & $8,0 \%$ & $9,0 \%$ & $22,0 \%$ \\
\hline \multirow[t]{4}{*}{ SWASTA } & Count & 0 & 8 & 10 & 18 \\
\hline & $\%$ within PEKERJAAN & $0,0 \%$ & $44,4 \%$ & $55,6 \%$ & $100,0 \%$ \\
\hline & $\%$ within ADOPSI & $0,0 \%$ & $21,1 \%$ & $18,5 \%$ & $18,0 \%$ \\
\hline & $\%$ of Total & $0,0 \%$ & $8,0 \%$ & $10,0 \%$ & $18,0 \%$ \\
\hline \multicolumn{2}{|c|}{ WIRASWAST Count } & & 2 & 17 & \\
\hline \multirow[t]{3}{*}{ A } & \% within PEKERJAAN & $0,0 \%$ & $10,5 \%$ & $89,5 \%$ & $100,0 \%$ \\
\hline & $\%$ within ADOPSI & $0,0 \%$ & $5,3 \%$ & $31,5 \%$ & $19,0 \%$ \\
\hline & $\%$ of Total & $0,0 \%$ & $2,0 \%$ & $17,0 \%$ & $19,0 \%$ \\
\hline \multirow[t]{4}{*}{ PENSIUNAN } & Count & 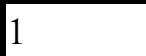 & 9 & 3 & 13 \\
\hline & \% within PEKERJAAN & $7,7 \%$ & $69,2 \%$ & $23,1 \%$ & $100,0 \%$ \\
\hline & $\%$ within ADOPSI & $12,5 \%$ & $23,7 \%$ & $5,6 \%$ & $13,0 \%$ \\
\hline & $\%$ of Total & $1,0 \%$ & $9,0 \%$ & $3,0 \%$ & $13,0 \%$ \\
\hline \multirow[t]{4}{*}{$\overline{\text { IBU-RT }}$} & Count & 2 & 5 & 2 & \\
\hline & \% within PEKERJAAN & $22,2 \%$ & $55,6 \%$ & $22,2 \%$ & $100,0 \%$ \\
\hline & $\%$ within ADOPSI & $25,0 \%$ & $13,2 \%$ & $3,7 \%$ & $9,0 \%$ \\
\hline & $\%$ of Total & $2,0 \%$ & $5,0 \%$ & $2,0 \%$ & $9,0 \%$ \\
\hline
\end{tabular}


PEKERJAAN * ADOPSI Crosstabulation

\begin{tabular}{|ll|l|l|l|l|}
\hline \multirow{2}{*}{ Total } & \multicolumn{3}{|c|}{ ADOPSI } & \multirow{2}{*}{ Total } \\
\cline { 3 - 5 } & Count & Rendah & Sedang & Tinggi & \multicolumn{1}{|c|}{ Ton } \\
\cline { 3 - 5 } & 8 & 38 & 54 & 100 \\
& \% within PEKERJAAN & $8,0 \%$ & $38,0 \%$ & $54,0 \%$ & $100,0 \%$ \\
& \% within ADOPSI & $100,0 \%$ & $100,0 \%$ & $100,0 \%$ & $100,0 \%$ \\
& \% of Total & $8,0 \%$ & $38,0 \%$ & $54,0 \%$ & $100,0 \%$ \\
\hline
\end{tabular}

Sumber: Hasil Olah Data Tim Peneliti tahun 2019

Berdasarkan tabel di atas hanya 8 responden dari 100 responden yang memiliki tingkat adopsi terhadap E-Banking rendah. Mereka adalah 1 orang pensiunan; 2 orang ibu rumah tangga dan 5 orang PNS. 9 responden Ibu Rumah Tangga, 2 orang ( 22,2 \%) memiliki daya adopsi tinggi sedangkan 5 orang memiliki daya adopsi sedang. Kelompok pensiunan yang berjumlah 13 responden, 9 orang diantaranya termasuk memiliki adaposi sedang dan 2 orang menunjukan daya adopsi terhadap E-Banking tinggi. Kelompok tersebut masih nyaman pada pelayanan perbankan face to face maupun menggunakan ATM.

Hasil Pearson Chi Squared 30,831 dengan signifikansi 0,001< 0,05 dan disimpulkan bahwa ada korelasi antara tingkat adopsi E-Banking dengan pekerjaan. Besarnya coefisien Contingency 0,485, berarti korelasi antara usia dengan tingkat adopsi belum kuat.

\subsection{Hubungan antara Tingkat Adopsi E-Banking dengan Pendidikan}

Tabel 5. Hubungan antara Tingkat Adopsi E-Banking dengan Pendidikan

\begin{tabular}{|c|c|c|c|c|c|c|}
\hline & \multicolumn{3}{|c|}{ Adopsi } & \multirow[b]{2}{*}{ Total } \\
\hline & & & Rendah & Sedang & Tinggi & \\
\hline \multirow[t]{17}{*}{ Pendidikan } & SLTA & Count & 1 & 9 & 11 & 21 \\
\hline & & $\%$ within Pendidikan & $4,8 \%$ & $42,9 \%$ & $52,4 \%$ & $100,0 \%$ \\
\hline & & \% within Adopsi & $12,5 \%$ & $23,7 \%$ & $20,4 \%$ & $21,0 \%$ \\
\hline & & $\%$ of Total & $1,0 \%$ & $9,0 \%$ & $11,0 \%$ & $21,0 \%$ \\
\hline & \multirow[t]{4}{*}{ D3 } & Count & 0 & 9 & 12 & 21 \\
\hline & & $\%$ within Pendidikan & $0,0 \%$ & $42,9 \%$ & $57,1 \%$ & $100,0 \%$ \\
\hline & & \% within Adopsi & $0,0 \%$ & $23,7 \%$ & $22,2 \%$ & $21,0 \%$ \\
\hline & & $\%$ of Total & $0,0 \%$ & $9,0 \%$ & $12,0 \%$ & $21,0 \%$ \\
\hline & \multirow[t]{4}{*}{ S1 } & Count & 4 & 10 & 13 & 27 \\
\hline & & $\%$ within Pendidikan & $14,8 \%$ & $37,0 \%$ & $48,1 \%$ & $100,0 \%$ \\
\hline & & \% within Adopsi & $50,0 \%$ & $26,3 \%$ & $24,1 \%$ & $27,0 \%$ \\
\hline & & $\%$ of Total & $4,0 \%$ & $10,0 \%$ & $13,0 \%$ & $27,0 \%$ \\
\hline & \multirow[t]{4}{*}{ S2 } & Count & 2 & 7 & 11 & 20 \\
\hline & & $\%$ within Pendidikan & $10,0 \%$ & $35,0 \%$ & $55,0 \%$ & $100,0 \%$ \\
\hline & & \% within Adopsi & $25,0 \%$ & $18,4 \%$ & $20,4 \%$ & $20,0 \%$ \\
\hline & & $\%$ of Total & $2,0 \%$ & $7,0 \%$ & $11,0 \%$ & $20,0 \%$ \\
\hline & S3 & Count & 1 & 3 & 7 & 11 \\
\hline
\end{tabular}




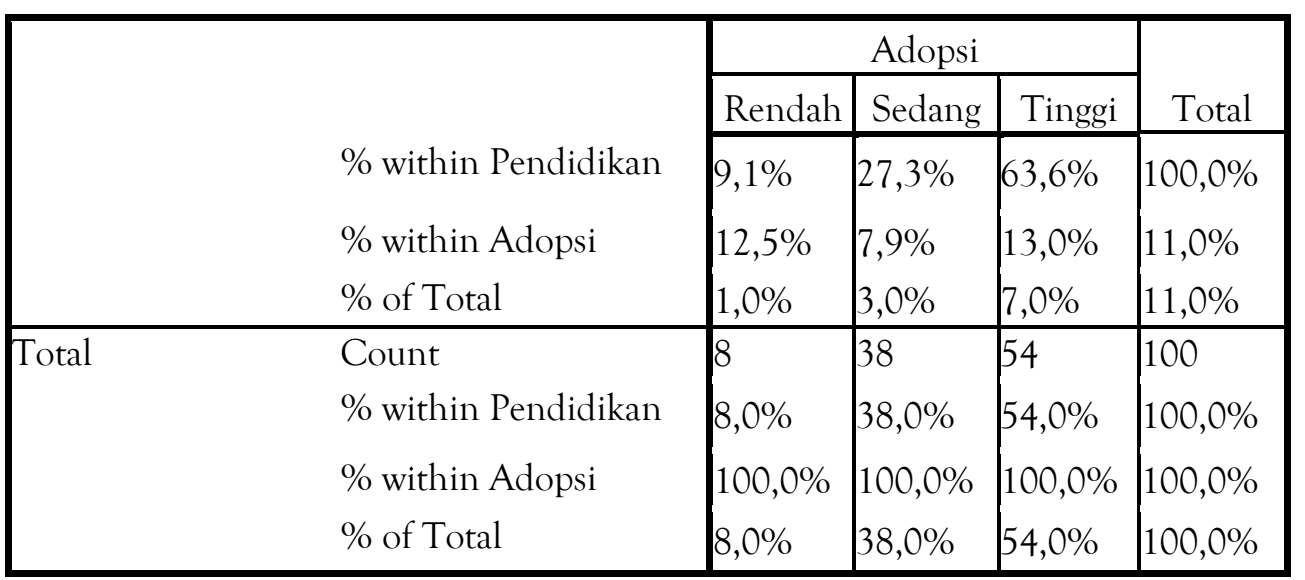

Sumber: Hasil Olah Data Tim Peneliti 2019

Tingkat pendidikan responden dikategorikan menjadi 5 yakni SLTA, D3, S1, S2 dan S3. Mahasiswa yang menjadi responden dianggap pendidikan tertingginya adalah SLTA.Dari 21 responden dengan tingkat pendidikan SLTA, 11 responden $(52,4 \%)$ mempunyai tingkat adopsi terhadap E-Banking tinggi; 9 responden (42,9\%) mempunyai tingkat adopsi sedang dan 1 orang responden mempunyai tingkat adopsi rendah. Situasi ini memperlihatkan bahwa tingkat adopsi responden dengan tingkat pendidikan SLTA dari sedang sampai tinggi dimungkinkan banyak mahasiswa yang menjadi responden. Responden dengan tingkat pendidikan D3, S1, S2 dan S3 pada umumnya memiliki daya adopsi terhadap E-Banking sedang sampai tinggi. Meskipun demikian masih ada diantara responden yang memiliki ti adopsi rendah.

Hasil penelitian memperlihatkan Pearson Chi-Square 4,700 dengan probabiliti signifikansi 0,789 jauh di atas 0,05. Hal ini dapat disimpulkan bahwa tidak ada hubungan antara tingkat pendidikan dengan daya adopsi E-Banking.

\section{PENUTUP}

Jumlah responden laki-laki dan perempuan seimbang masing-masing 50 orang. Dilihat dari jenis pekerjaan, pekerjaan responden bervariasi .Status responden mulai mahasiswa ,masih bekerja sampai pensiun. 59 responden bekerja baik sebagai pegawai negeri, pegawai swasta maupun bekerja mandiri atau wiraswasta. Mahasiswa berjumlah 19 orang , 13 responden telah pensiun dan 9 responden adalah ibu rumah tangga. Tingkat pendidikan responden mulai SLTA sampai S3. Karena masih berstatus mahasiswa D3/S1 maka tingkat pendidikan dikategorikan SLTA dan hanya 11 responden berstatus S3. Alasan menggunakan E-Banking adalah dapat digunakan setiap saat, hemat waktu dan energi;fitur lengkap dan sesuai kebutuhan;tidak menggunakan peralatan khusus; kerahasiaan terjamin dan akses mudah

Hasil analisis secara statistik antara variabel demografi dengan tingkat adopsi memperlihatkan bahwa gender dan pendidikan tidak ada hubungan dengan tingkat adopsi terhadap E-Banking sedangkan pekerjaan dan usia berkorelasi dengan tingkat adopsi E-Banking. 


\section{DAFTAR PUSTAKA}

A.A.,Chaudhry, A.,Parveiz, Y.,Javed.2016. Determinants of Users Trust for Branchless Banking in Pakistan. Journal of Internet Banking and Commerce. April 2016, vol. 21, no. 1.

Akturan,U. dan Tezean,N.2012.Mobile Banking Adoption of The Youth Market: Perception and Intentions.Marketing Intelligence \& Planning.30 (4):444-459.

Chen,C.S.2013.Perceived Risk,Usage Frequency of Mobile Banking Services. Managing Service Quality,23 (5): 410-436.

Chongo,Pamela John dan Sedoyeka Eliamani. 2014.Exploring Factors Affecting Mobile Money Adoption in Tanzania.International Journal of Computing and ICT research, Vo.8.

Cudjoe,A.G.,Anim,P.A., dan Nyanyofio,J.G.N.T. 2015.Determinants of Mobile Banking Adoption in the Ghanaian Banking Industry: A case of access Bank Ghimaana Limited.Journal of Computer and Communication.3:1-9.

Curran,J.M. dan Meuter,M.L.2005.Self Service Technology Adoption:Comparing Three Technologies.Journal of Services Marketing, 19 (2), PP.103-113.

Ghobakhloo,Morteda; Hong,Tang Sa;Sabouri,Mohammad Sadegh dan Zulkifli,Norzima.2012 Strategies for Successful Information Technology Adoption in Small and Medium-sized Enterprises. Information, 3.

Indaryani,Tri.2017. Pengguna e-Banking Indonesia Naik 270 Persen. Ini Target Keuangan Digital 2020. http://batam.tribunnews.com/2017/04/19/penggunae-banking-indonesia-naik-270-persen-ini-target-keuangan-digital-2020? page=3.

Diunduh tanggal 22 Desember 2018.

Mahayana,Dimitri.Akankah Financial Tech Menggeser Perbankan Konvensional ? https://sharingvision.com/akankah-finacial-tech-menggeser-perbankan konvensional/.Diunduh 12 Januari 2019.

Mundy,Paul.2000.Adopsi dan Adaptasi Teknologi Baru.PAATP3.Bogor.

Ndumba,Hannah Wangari dan Muturi Wiily.2014. Factors Affecting Adoption of Mobile Banking in Kenya: Case Studiy of Kenya Commercial Bank Limuru. International Journal of Social Sciences Management and Enterpreneurship 1(3): 92-112,November.

Shang Wu,Feng dan Shen Yen,Yung.2014. Factors Influencing the Use of Mobile Financial Services:Evidence from Taiwan.Modern Economy,pp.12211228.2,June.

Shi, Xiaguang.2011. Exploring Factors that Hinder the Adoption of Mobile Services in China.A Qualitative User Analysis with Special Focus on Mobile Financial Services. 